\title{
INSTITUTIONAL PROVISION OF DESTINATION MANAGEMENT IN THE MOST IMPORTANT AND IN THE CRISIS PERIOD THE MOST VULNERABLE REGIONS OF TOURISM IN SLOVAKIA
}

\author{
Anna Michálková, Jozef Gáll ${ }^{1}$
}

\footnotetext{
${ }^{1}$ Ass. Prof. Ing. Anna Michálková, PhD., e-mail: anna.michalkova@euba.sk, ORCID 0000-0002-9084-4930; Ing. Jozef Gáll, e-mail: jozef.gall@euba.sk, ORCID 0000-0002-2520-4929, University of Economics in Bratislava, Faculty of Commerce, Department of Services and Tourism, Dolnozemská cesta 1, 85235 Bratislava (Slovak Republic)
} 
Abstract: The aim of the presented paper is to examine the specific situation in the institutional provision of tourism in Slovakia with special regard to the most important and in the crisis period the most vulnerable tourism regions, their identification is a partial goal of the paper. With regard to the current crisis period, the survey is supplemented by identifying factors of employment change, focusing mainly on the region's competitiveness in tourism. The importance of regions is assessed in the article on the basis of potential for tourism development, further in terms of their importance for tourism in Slovakia based on tourism performance expressed by the number of overnight stays and on the basis of industry concentration of tourism measured by employment in tourism. We consider the most vulnerable regions to be those that reach the level of specialization in tourism (based on the localization coefficient) and it has a growing tendency. The research results show that the importance of regional competitiveness in tourism for employment change (which is a regional component) is very different despite the established destination management, it is even negative, and in the case of positive figures, it is without an obvious advantage over other factors analyzed in the shift-share analysis. Also, it is possible that the current crisis period caused by measures in connection with the COVID-19 pandemic will help to find endogenous solutions to fragmented destination management in the most important and vulnerable tourism regions, or legislative solutions related to the amendment to the Tourism Promotion Act.

Key Words: destination management organizations, tourism cluster organizations, tourist regions of Slovakia, shift-share analysis, localization coefficient

Abstrakt: Ciel'om predloženej state je skúmanie špecifickej situácie v inštitucionálnom zabezpečení cestovného ruchu na Slovensku s osobitným zretelom na najvýznamnejšie a v krízovom období najzranitel'nejšie regióny cestovného ruchu, ich identifikácia je čiastkovým ciel'om state. Skúmanie je vzhl'adom na aktuálne krízové obdobie doplnené zist'ovaním faktorov zmeny zamestnanosti sústred'ujúc sa najmä na konkurencieschopnost' regiónu v CR. Významnost' regiónov je v stati posudzovaná na základe potenciálu pre rozvoj cestovného ruchu, d’alej z hl'adiska ich významnosti pre cestovný ruch Slovenska vychádzajúc $z$ výkonov cestovného ruchu vyjadrených počtom prenocovaní a na základe odvetvovej koncentrácie cestovného ruchu meranej zamestnanost'ou v cestovnom ruchu. Medzi najzranitel'nejšie regióny pokladáme tie, ktoré dosahujú úroveň špecializácie na cestovný ruch (na základe koeficientu lokalizácie) a táto má rastúcu tendenciu. Výsledky ukazujú, že význam konkurencieschopnosti regiónov $v$ cestovnom ruchu pre zmenu zamestnanosti (regionálny komponent) je napriek vybudovanému destinačnému manažmentu vel'mi rozdielny, dokonca je aj negatívny a v prípade pozitívneho bez zrejmého náskoku pred ostatnými faktormi analyzovanými v shift-share analýze. Je možné, že práve aktuálne krízové obdobie spôsobené opatreniami v súvislosti s pandémiou COVID-19 napomôže hladaniu endogénnych riešení roztriešteného destinačného manažmentu $v$ najvýznamnejších a aj v najzranitel'nejších regiónoch cestovného ruchu, príp. sa budú hladat' aj legislatívne riešenia súvisiace s úpravou zákona o podpore cestovného ruchu.

Klúčové slová: organizácie destinačného manažmentu, klastrové organizácie cestovného ruchu, slovenské regióny cestovného ruchu, shift-share analýza, lokalizačný koeficient

\section{Highlights:}

- Tourism regions in Slovakia have different institutional arrangements.

- Liptov and Orava tourism regions can be considered the riskiest in times of crisis. 
- These regions have well-established destination management at the institutional level, but the regional competitiveness of tourism does not clearly have a positive position in them.

- In order to maintain the socio-economic level, especially of the most vulnerable regions, it is important to restore jobs in tourism.

\section{Introduction}

The current situation in the institutional provision of destination management in Slovakia can be considered very specific. The operation of several identical / similar institutions and their activities in one region under different "headings" and the meaningfulness of their support from public sources for the development of tourism is questionable. It is especially interesting to examine what it looks like with the institutional provision of destination management in the most important regions of tourism in Slovakia and in regions that specialize in tourism. It is necessary to gradually analyze this situation, look for tools to organize destination management in our country and adjust the model of its operation towards the conceptual development of tourism in the regions, increasing their competitiveness and meaningful use of public resources.

The systematic support of regional tourism and the implementation of destination management began after 30 years of various efforts to find a systemic solution. However, in some regions, DMOs have been "overtaken" in time by tourism clusters. They have been a part of tourism in Slovak regions since 2008 and were created mainly as a reaction to the dragging systemic solution in building destination management, as well as the need to replace the missing functional regional tourism management, while also using economic and regional policy instruments to support entrepreneurship and support for clustering from European sources. However, cluster organizations kept being established even later on, due to non-compliance with the minimum legal conditions for the establishment of DMOs under the Slovak law, which came into effect in 2010.

DMOs established under Act Nr. 91/2010 of Coll. on Support of Tourism should create conditions for the development of tourism in their territory, represent the interests of their members and use public resources for these purposes in the form of subsidies from the state budget and membership fees (since most members belong to the public sector). Local tourism organisation (LTO) consists of at least five municipalities where a summary of the number of overnight stays by visitors in accommodation establishments in the founding municipalities in the previous calendar year was at least 150,000. LTO may be established also by less than five municipalities in case when a summary of the number of overnight stays by visitors was at least 250,000. Except the municipalities, members of LTO may also be the natural or legal persons that do business or operate on their territory. Members of LTO pay a membership fee which is set by the General Assembly of LTO and may differ among LTOs. The grant from the State budget is provided for the financial year. An LTO can receive the grant in the same amount as is the total sum of membership fees collected in the year prior to the previous financial year. The maximum amount of the grant may not exceed $90 \%$ of the total overnight tax collected in all member municipalities in the year prior to the previous financial year. The main income of LTOs consists of membership fees and grants made under the law on the promotion of tourism. Since 2011 until now 38 LTOs have been established in Slovakia. On average, one LTO has 25 members, with municipalities and cities representing almost $40 \%$ (as of January 2020). Other member entities come from the business sphere and self-government of interest. (For more detailed information on the activities of destination management organizations in Slovakia, see e.g. Michálková and Fúrová, 2017.)

Cluster organizations do not have "their own" law - most of them operate as civic associations. In the case of cluster organizations, the effort to bring together territorially close entities for the purposes of cooperation, innovation and the development of competitiveness was supported by public resources partly from the state budget to support clustering and especially by the EU Structural Funds in the EU budget period 2007 - 2013. Public resources have flowed to cluster organizations without a clear cluster policy. Cluster organizations are mainly client-oriented and focus primarily on the implementation of marketing tasks and coordination of marketing activities, 
participation in product creation, organization of events, in the field of innovation, especially product innovations and innovations in the field of promotional activities. Several tourism clusters are registered in the cluster union. However, in fact, in some regions and/or subregions, they replace non-existent destination management, fulfilling the role of destination management to varying degrees and in various forms (Michálková, Némethová and Kojdová, 2012; Michálková and Gajdoš, 2015).

The institutional provision of tourism in the regions is important for the successful competition of the regions and the growth of their competitiveness. The importance of the competitiveness of regions is constantly growing, and there are more and more opinions that regions and destinations are the carriers of national competitiveness. One of the crucial parameters of competitiveness, which makes it possible to assess the ability of an industry to use its available conditions, is sector concentration (Dwyer and Kim, 2003). Changes in the sectoral concentration of regions can contribute to both labor force growth and its decline (Aiginger and Davies, 2004). Such structural changes in the regional economic environment can be analysed by so-called shift-share analysis (Sambidi, 2008). Monitoring these changes is an appropriate measure, as the importance of tourism in job generation is essential in terms of its contribution to the regional and national economy (Indrová et al., 2008).

\section{Theoretical background}

The traditional feature of today is the constant development, increasing competition and also the growing demands of visitors in tourism destinations (Benešová, Kubičková and Krošláková, 2013). In order to strengthen the competitiveness of the regions, strategic thinking and methodologies have become important tools for managing tourism destinations, resulting in destination management (Laesser and Beritelli, 2013). The professional literature in connection with destination management is largely based on the experience and knowledge of Western European countries. For example, Bieger and Beritelli (2012) and Kaspar (1995) base their theories on case studies from the European Alps, which are also linked to the first management organization founded in St. Moritz (Gajdošík, 2019) and on the examples of the German state of Bremen (Luft, 2001). The issue of destination management as a part of tourism organization and management is processed mainly by foreign literature (Pechlaner et al., 2015; Meriläinen and Lemmetyinen, 2011; Pearce, 2015; Mira, 2016) and somewhat sporadically also by professional literature in the conditions of Slovakia (Michálková, 2010a; Novacká et al., 2013; Gajdošík, 2019). Tourism destination competitiveness is solved in the studies of many authors, with several developing the issue comprehensively in the form of models (for example, Ritchie and Crouch, 2010; Estêvão and Ferreira, 2015; Dupeyras and MacCallum, 2013 and many others).

The concept of destination management is based on the understanding that networking, strategic location and branding will increase the competitiveness of the destination in the long run. Cooperation and the creation of regional networks have thus become key factors in destination management (Michálková, 2010b). Fesenmaier and Xiang (2017) understand destination management as a set of coordinated techniques, tools and measures applied in the planning, organization, communication, decision-making process and regulation of destination tourism. Destination management is a comprehensive management process with regard to the specifics of tourism, which includes the implementation of a wide range of activities with emphasis on their effectiveness in order to achieve the maximum positive impacts of tourism on the destination (Gajdošík, 2019). In order to do this, it is necessary to take into account the main attributes related to the building of destination management, which the author Michálková (2013) specified with the following scheme. 


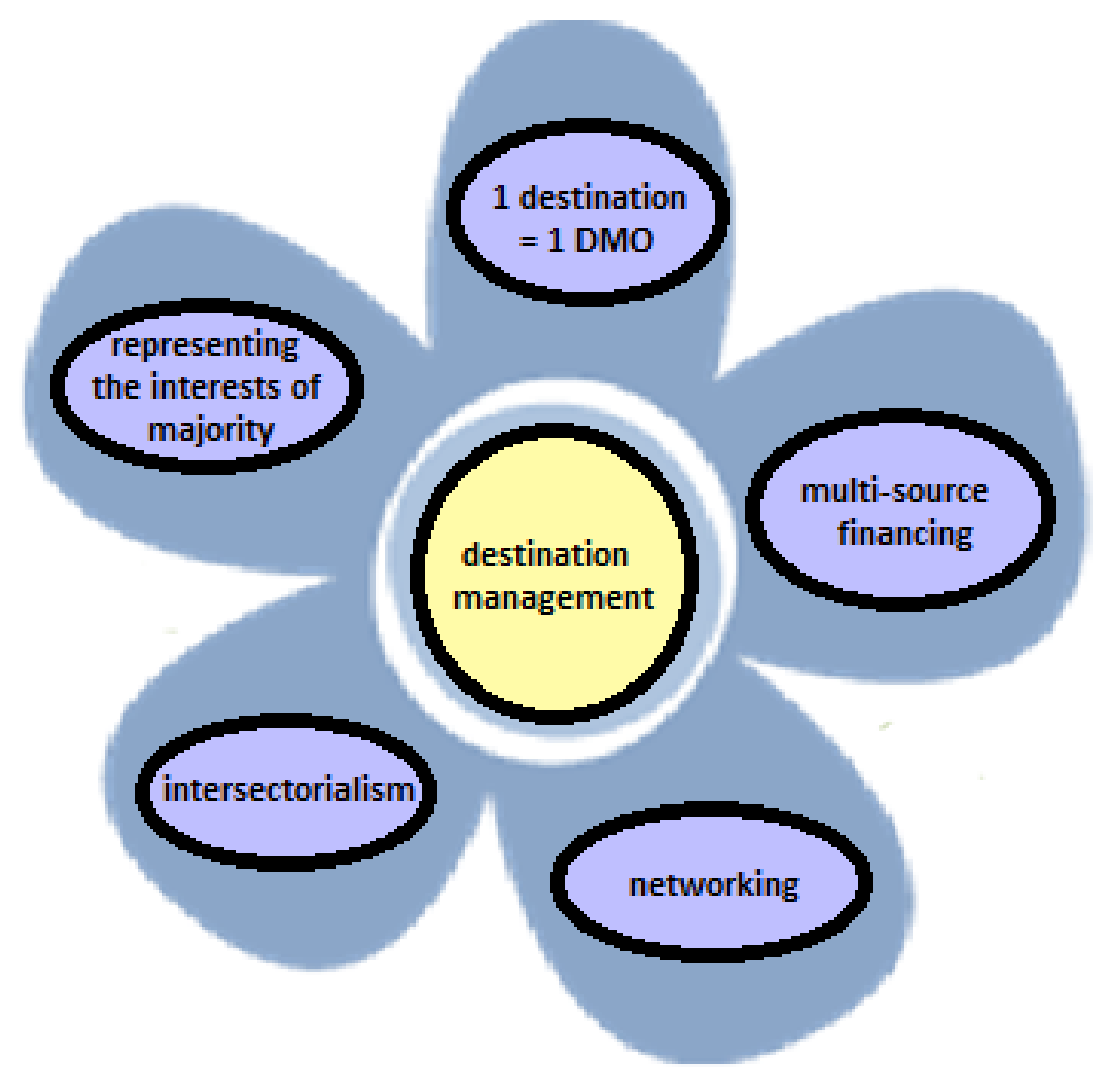

Fig 1. The flower of destination management in tourism. Source: Michálková (2013)

In order to implement the above activities, there is a clear need for (professional) human resources and an organizational structure responsible for managing the destination. The tasks described above are covered by the Destination Management Organization (DMO). The organization of destination management does not have a uniform definition in the literature. The authors use the terms "tourist organization" (Bieger and Beritelli, 2012), "tourism organization" (Királová, 2004) or "destination society (Holešinská, 2012) and at the same time assign different functions to these organizations. According to the UNWTO (2007), in addition to typical marketing activities, DMOs should manage and coordinate destination activities as part of a coherent strategy and provide stakeholders with the necessary resources and know-how to achieve their common goals.

Bratl and Schmidt (1998) argue that destination management is a strategy and a way for strong regions that concentrate their efforts on the joint development, organization and active sale of their key competitive advantages. The competitive advantages of tourism, including regional benefits from industry concentration, are revealed by shift-share analysis (Knudsen, 2000). The shift-share analysis of a selected quantity is focused on one of the following aspects - on the assessment of the dynamics and structural changes of the selected quantity in terms of individual industries or on the static evaluation of structural changes in terms of individual industries and regions. This metric is (despite the above aspects) generally used to describe regional and industrial economic growth and to examine the structural effect and regional or industrial competitiveness that emphasizes changes over time (Sirakaya-Turk, Uysal, and Toepper, 1995). The regional shift component refers to whether the local economy moved into faster (dynamic) or slower growth sectors. The national share component component then measures whether the larger or smaller share of growth occurs in a given sector in a given region (Kiser, 1992) Shift-share analysis has been applied in the fields of regional and political economy, marketing, geography and urban planning for more than four decades. It has also appeared in the tourism sector in recent years, although studies of this context are still relatively rare (Fuchs et al., 2000; Toh, Khan and Koh, 2001; Sirakaya-Turk, Choi and Var, 2002; Toh, Khan and Lim., 2004; Primont and Domanzlicky, 2008). Shift-share analysis is based primarily on the concentration of industry in the research area. Regional concentration of industries represents 
the location of several well-defined industries in the region (Brakman, Garretsen, and van Marrewijk, 2001). The origin of sectoral concentration in a region may be related to very different factors. While some industries may be concentrated due to the availability of specific resources, proximity to consumer markets, or even as a historical accident, other industries do not have a natural tendency to a concentrated location (Mori, Nikishimi, and Smith, 2005). The other aspect of the wider applicability of the shift-share analysis is its ability to fit any regional scale of the analysis. In fact, as far as the definition of the term region refers to the part of a whole, the studies applying shift-share analysis can then be designed on the level of country groups/communities (Bielik and Rajčániová, 2008; Ray and Harvey, 1995), individual countries (Kowalewsi 2011; Klein, Kies and Schulte, 2009) or the region itself subtracted from the nation (Herath, Gebremedhin and Maube, 2011). The localization coefficient, which was first applied in a regional analysis in 1965 (Haggett, 1965), is most often used to quantify the concentration of a particular industry. According to several authors (Hoover, 1936; Kim, 1995; Xu, Cheng and Xu, 2018, Gáll and Strežo, 2019), it is an effective tool that allows to evaluate the strength and size of a particular industry in the region. The use of a localization coefficient is an effective way to identify growth opportunities and comparable regional benefits. Quantifying the relative importance of the sector for the regional economy can also help predict the impact of industrial growth or decline on regional economic health (Porter, 1998).

In the context of destination management, we can also talk about crisis management, and therefore in our article, we will point out the most vulnerable regions in the pandemic period, which has been going on since March 2020. Tourism is one of the sectors hardest hit by the coronavirus pandemic, as measures introduced to contain the virus led to a near-complete cessation of tourism activities around the world (UNWTO, 2020). In the conditions of Slovakia, this situation had fatal consequences for many accommodation and catering facilities, especially for small and medium-sized enterprises, or caused major problems for the survival of their business activities. The restraint of the Slovak population in travel and travel activities has raised concerns about the development of consumer behaviour in the coming period in the field of travel and tourism (Özoğlu and Gáll, 2020). Available data published by the Statistical Office of the Slovak Republic (2020b) on the development of tourism in 2020 show a decrease in all tourism indicators (except for the average number of overnight stays). The negative impact of the pandemic can be observed mainly in less developed tourism regions. According to the OECD publication (2020), the tourism sector will be very different in 2021 to what it was in 2019. The longer the crisis continues, the more businesses and jobs will be lost, the greater the implications for traveller behaviour, and the tougher it will be to rebuild the tourism economy.

\section{Objective and methodology}

Destination management of tourism in Slovakia is developing in a special way. There are diametrically different destination management organizations in the regions of Slovakia in terms of their membership base size, territory size and financial strength. Their activities are intertwined in the area with tourism clusters with a similar focus. In particular, it is important to examine how institutionally secured destination management is, especially in our most important regions and in our most vulnerable regions, which specialize in tourism.

The aim of the presented paper is to examine the specific situation in the institutional provision of tourism in Slovakia with special regard to the most important and in the crisis period the most vulnerable tourism regions, with their identification as a partial goal of the paper. Given the current crisis period caused by the measures in connection with the COVID-19 pandemic, the survey is supplemented by identifying factors of employment change, focusing in particular on the region's competitiveness in tourism. In the paper, the regions are selected on the basis of their potential for tourism development, in terms of their importance for Slovakia's tourism based on tourism performance expressed by the number of overnight stays and in terms of the importance of tourism in the regions based on their industry concentration of tourism. Only regions of the $1^{\text {st }}$ category with international significance, regions achieving an above-average number of overnight stays and regions with an above-average sectoral concentration of tourism are examined. Institutional security is examined in the context of DMOs established on the basis of 
Tourism Promotion Act (2010). As we stated in the introduction to the paper, in the past, tourism clusters (until the effectiveness of the Tourism Promotion Act) had served as non-existent DMOs, which have been active in particular regions. Therefore, we included these ones in the survey.

In our research, we rely on statistical data on the number of overnight stays in 2018 . The evaluation of tourism concentration in the regions (location coefficient) and determination of employment change factors in the regions (shift-share analysis) is based on employment data for individual tourism regions in 2018 in comparison with 2012 (this year is significant in regional tourism in Slovakia in connection with the Tourism Promotion Act and the establishment of the majority of the DMOs) and 2007. In terms of potential, the regions were selected on the basis of the regionalization of tourism and the Tourism Strategy up to 2020.

The starting point of our research is the current mapping of existing destination management organizations based on the available register of the Ministry of Transport and Construction of the Slovak Republic. Using the obtained data, it was possible to create a map of local tourism organizations (LTOs) in the R Project for Statistical Computing with their membership base and designation of the headquarters. At the end of 2011, the first three DMOs were established, and the majority of the others were established in 2012 (a total of 31 LTOs out of the current 38 LTOs).

The location coefficient is a method used to identify clusters formed from local businesses and institutions in a particular industrial area, based on regional employment data. The calculation of LQ according to Porter (1998) represents the share of the sector in employment in the region compared to the national share. This relationship can be expressed as follows:

$$
L Q=\frac{\text { local }_{i} / \text { local }}{S R_{i} / S R}
$$

where

LQ $\quad$... location coefficient

local ${ }_{i} \ldots$ number of employees in the sector $i$ in the region

local ... total number of employees in the region

$\mathrm{SR}_{\mathrm{i}} \quad \ldots$ number of employees in the sector $i$ at a higher level

SR ... total number of employees at a higher level 


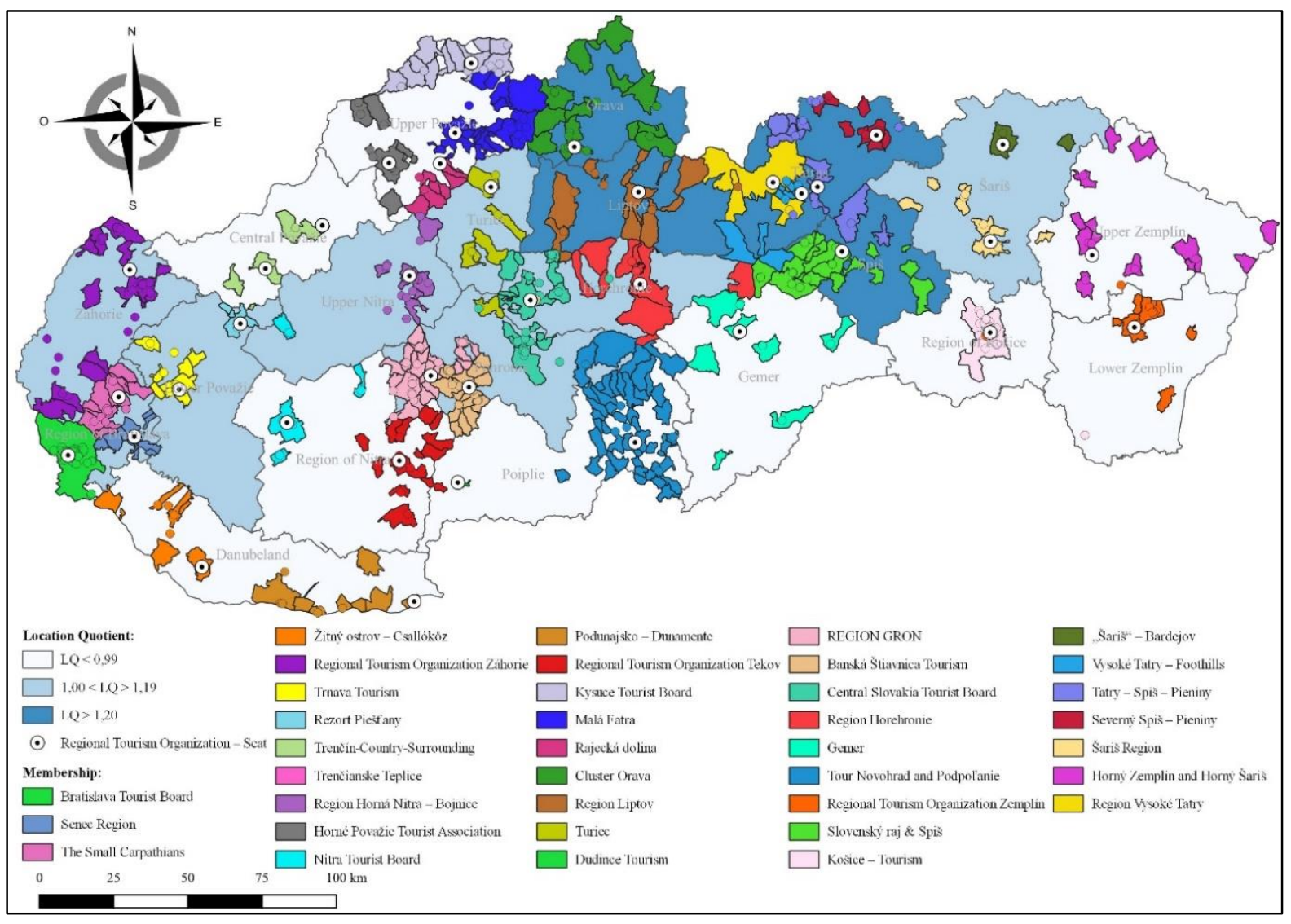

Fig 2. Map of LTOs in Slovakia with identification of sectoral concentration of tourism in regions. Source: processed by the authors using statistical program $R$ according to data by Register of the Local Tourism Organisations, Ministry of Transport and Construction of the Slovak Republic (2020) and database Employees by economic activity collected through workplace method, Statistical Office of the Slovak Republic (2019)

Shift-share analysis is a method of data analysis that seeks to determine the extent to which regional job growth can be attributed to a national trend and to what extent due to a unique regional factor. The purpose of this tool is to analyze changes in economic output or employment by industry by assessing their performance, including the growth of employment in a particular sector in the region compared to the national level. Shift-share analysis is based on the assumption that regional economic growth is influenced by a combination of the effects of three basic components - national growth, growth in individual sectors and growth that is caused by regional factors (Primont and Domanzlicky, 2008). The national share component measures how much total employment in the region has increased due to the growth of the national economy during the period analyzed. The industrial mix component identifies fast-growing or slow-growing industries in the region based on the national growth rates for each sector. The effect of regional competitiveness is the most important component of shift-share analysis, as it explains how much of the change in a particular industry results in the unambiguous competitive advantage that the region has. The detailed analysis of the individual components of shift-share analysis and their mathematical expression is based on the work of Sambidi (2008):

$$
\begin{aligned}
& N S=\text { local }_{i}^{t-1} x\left(\frac{S R^{t}}{S R^{t-1}}-1\right) \\
& I M=\text { local }_{i}^{t-1} x\left[\left(\frac{S R_{i}^{t}}{S R_{i}^{t-1}}\right)-\left(\frac{S R^{t}}{S R^{t-1}}\right)\right] \\
& R S=\text { local }_{i}^{t-1} x\left[\left(\frac{\text { local }_{i}^{t}}{\text { local }_{i}^{t-1}}\right)-\left(\frac{S R_{i}^{t}}{S R_{i}^{t-1}}\right)\right]
\end{aligned}
$$


where

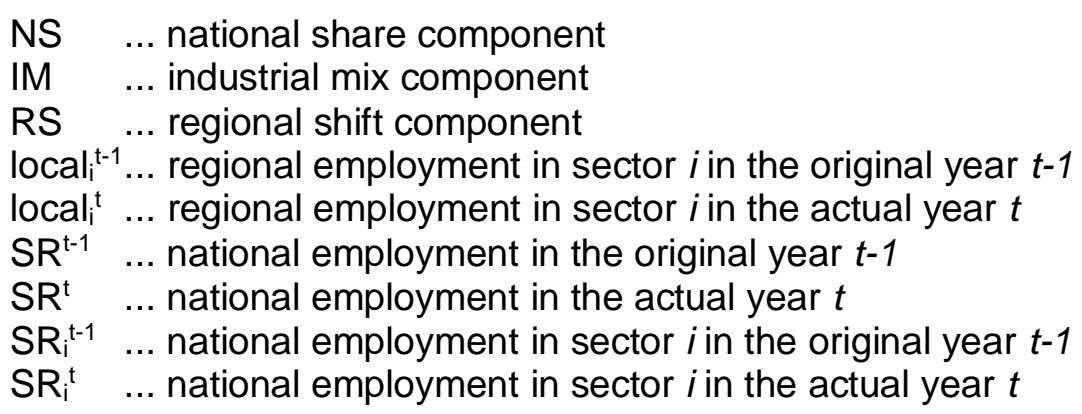

The total change in employment in the region represents the sum of all three of the above components:

$$
T E C=N S+I M+R S
$$

\section{Results}

\subsection{The most important regions of tourism}

We assess the importance of regions in tourism on the basis of three factors - the potential for tourism development, their importance for tourism in Slovakia based on the performance of tourism and the industry concentration of tourism. From the 21 tourism regions in Slovakia, 8 regions are among the most important ones in terms of potential, namely Region of Bratislava, Upper Považie, Turiec, Orava, Liptov, Horehronie, Tatras and Spiš (Tourism Strategy up to 2020, Ministry of Transport, Construction and Regional Development of the Slovak Republic, 2014). These are regions of the $1^{\text {st }}$ category, with international significance (categorized on the basis of their potential for tourism). In terms of the number of overnight stays, the most important tourist regions are Region of Bratislava, Tatras, Liptov, Upper Považie, Lower Považie and Region of Nitra (they reach an above-average number of overnight stays, based on data from 2018).

The regions that currently (in 2018) reach an above-average number of overnight stays belong (except for the two regions - Lower Považie and Region of Nitra) to the $1^{\text {st }}$ category regions. On the contrary, several regions with high potential, especially with regard to localization assumptions and their originality, such as regions of Orava or Spiš, belong to the regions with the lowest number of overnight stays. These are regions that are rather smaller in area, but at the same time are mainly focused on recreational tourism with a low share of business tourism. However, these regions achieve above-average sectoral concentration in tourism (according to LQ values, Tab. 2). Tourism has a significant representation in the economic structure of individual tourism regions in all regions, which are assessed in terms of their potential as the most important (outside the Region of Upper Považie). On the other hand, tourism is also an important economic sector in the regions, which are classified in a lower category in terms of their potential and have only a national, or supraregional significance. Based on the localization coefficient, such regions include the region of Záhorie, Lower Považie, Upper Nitra, Turiec, Pohronie and Šariš (LQ for 2018). However, all regions reaching the highest values of the localization coefficient, namely the regions of Liptov, Orava, Tatras and Spiš, belong to the $1^{\text {st }}$ category regions of international importance. The regions of tourism that are above average in all three examined criteria are the regions of Tatras and Liptov. Monitoring the growth in the number of overnight stays compared to the initial year (2018/2012), when most destination management organizations were established, is partly misleading due to the abolition of part of illegal accommodation in connection with the minimum number of overnight stays for DMOs and the possibility of drawing subsidies under the Tourism Promotion Act. DMOs were created differently in different regions, and thus the official recognition of overnight stays in them (dismantling of illegal accommodation) took place in different years. Apart from this, above-average growth in the number of overnight stays is achieved by all $1^{\text {st }}$ category regions (except for region of Spiš - its growth is near the average) 
and the regions included in lower categories achieve growth in the number of overnight stays, but below average in Slovak conditions.

Tab 1. Number of overnight stays in the tourist regions in 2018 and 2012; Growth Index of overnight stays in 2018 and 2012; DTS - Domestic Tourism Share. Source: processed by the authors according to database Capacity and performances of accommodation facilities by districts, Statistical Office of the Slovak Republic (2020a)

\begin{tabular}{c||c||c||c||c}
\multicolumn{1}{c||}{ Tourist Region } & \multicolumn{2}{c|}{ Overnight Stays Nr } & Growth & DTS \\
& $\mathbf{2 0 1 2}$ & $\mathbf{2 0 1 8}$ & Index & in \%, 2018 \\
\hline \hline Region of Bratislava & 1927156 & 3025339 & 1.57 & 34.7 \\
\hline Danubeland & 196722 & 315325 & 1.60 & 49.9 \\
Záhorie & 176656 & 219159 & 1.24 & 61.8 \\
\hline Lower Považie & 801348 & 942028 & 1.18 & 59.9 \\
\hline Central Považie & 431096 & 674504 & 1.56 & 65.3 \\
\hline Region of Nitra & 494202 & 842255 & 1.70 & 58.2 \\
\hline Upper Nitra & 390071 & 508322 & 1.30 & 75.8 \\
\hline Upper Považie & 653823 & 1037598 & 1.59 & 68.4 \\
\hline Turiec & 329862 & 387913 & 1.18 & 75.1 \\
\hline Orava & 203459 & 286132 & 1.41 & 74.7 \\
Liptov & 1252918 & 1719368 & 1.37 & 62.7 \\
Poiplie & 351195 & 472719 & 1.35 & 84.3 \\
Gemer & 160312 & 176092 & 1.10 & 81.3 \\
\hline Horehronie & 375464 & 522550 & 1.39 & 81.3 \\
Pohronie & 494619 & 700077 & 1.42 & 85.1 \\
\hline Tatras & 1636040 & 2266619 & 1.39 & 68.1 \\
Spiš & 165908 & 219246 & 1.32 & 64.0 \\
\hline Region of Košice & 281726 & 407210 & 1.45 & 60.0 \\
Šariš & 380992 & 497772 & 1.31 & 74.2 \\
\hline Upper Zemplín & 71772 & 61884 & 0.86 & 84.4 \\
Lower Zemplín & 102274 & 124319 & 1.22 & 80.0 \\
\hline \hline
\end{tabular}


Tab 2. Values of the localization coefficient of the concentration of the tourism industry in the regions of Slovakia (2018, 2012 and growth index 2018/2012). Source: processed by the authors according to database Employees by economic activity collected through workplace method, Statistical Office of the Slovak Republic (2019)

\begin{tabular}{|c|c|c|c|}
\hline \multirow{2}{*}{ Tourist Region } & \multicolumn{2}{|c|}{ LQ } & \multirow{2}{*}{$\begin{array}{c}\text { Growth } \\
\text { Index of } \\
\text { LQ }\end{array}$} \\
\hline & 2018 & 2012 & \\
\hline Region of Bratislava & 1.05 & 1.10 & 0.95 \\
\hline Danubeland & 0.48 & 0.84 & 0.57 \\
\hline Záhorie & 1.06 & 1.13 & 0.94 \\
\hline Lower Považie & 1.01 & 0.84 & 1.20 \\
\hline Central Považie & 0.99 & 0.92 & 1.08 \\
\hline Region of Nitra & 0.81 & 0.83 & 0.98 \\
\hline Upper Nitra & 1.17 & 1.23 & 0.95 \\
\hline Upper Považie & 0.90 & 0.73 & 1.23 \\
\hline Turiec & 1.19 & 1.42 & 0.84 \\
\hline Orava & 1.61 & 1.16 & 1.39 \\
\hline Liptov & 2.16 & 1.91 & 1.13 \\
\hline Poiplie & 0.33 & 0.47 & 0.70 \\
\hline Gemer & 0.35 & 0.39 & 0.90 \\
\hline Horehronie & 1.13 & 1.07 & 1.06 \\
\hline Pohronie & 1.08 & 1.02 & 1.06 \\
\hline Tatras & 1.23 & 1.51 & 0.81 \\
\hline Spiš & 1.51 & 1.86 & 0.81 \\
\hline Region of Košice & 0.84 & 0.94 & 0.89 \\
\hline Šariš & 1.13 & 1.01 & 1.12 \\
\hline Upper Zemplín & 0.49 & 0.50 & 0.98 \\
\hline Lower Zemplín & 0.78 & 0.66 & 1.18 \\
\hline
\end{tabular}

Currently (year 2018), the level of regional specialization (LQ values above 1.2) is achieved by only 4 tourist regions (out of 21 tourist regions in Slovakia), namely the region of Liptov, and (with a significant gap) regions of Orava and Spiš and the region of the Tatras. The level of regional specialization in tourism was reached in 2012 , when the majority of DMOs were established, all these mentioned regions except for the region of Orava, in which the LQ value reached the lower limit of 1.2. The Liptov region had the highest value of all regions. LTO was established in all these regions this very year. In 2012, two other regions reached the level of regional specialization in tourism, namely the regions of Turiec and Upper Nitra. Currently (2018), however, they reached an above-average concentration of tourism (localization coefficient of geographical concentration between the values of $1.01-1.19$, Tab. 2) together with the regions of Horehronie, Sariš, Pohronie, Záhorie, Region of Bratislava and Lower Považie. On one hand, in the region of Bratislava, including Upper Nitra and Turiec, the values of the concentration of the territory on tourism are decreasing, on the other hand, in the region of Horehronie, Pohronie and Sariš the value is increasing. On one hand, among the examined regions, the highest increases in the concentration of tourism in the region (above-average growth compared to 2012) were achieved by the regions of Orava, Upper Považie, Lower Považie, Liptov, Šariš, Central Považie, Pohronie and Horehronie. On the other hand, the region of Spiš, Tatras and Turiec have the largest decline, all of which are regions with a sectoral specialization in tourism (value 1.2 and higher).

Although the concentration on tourism in the regions highlights the importance of this sector for the region and indicates the ability of the territory to benefit from favourable conditions for tourism, shift-share analysis can reveal which factors are responsible for changes in employment in 
the monitored regions. This analysis is carried out for the most identified and important regions of tourism listed in Tab. 3.

Tab 3. Results of shift-share analysis of most important tourist regions in Slovak republic (2012-2018). Source: processed by the authors according to database Employees by economic activity collected through workplace method, Statistical Office of the Slovak Republic (2019)

\begin{tabular}{c||c||c||c||c} 
Tourist Region & $\begin{array}{c}\text { National share } \\
\text { component }\end{array}$ & $\begin{array}{c}\text { Industrial mix } \\
\text { component }\end{array}$ & $\begin{array}{c}\text { Regional shift } \\
\text { component }\end{array}$ & $\begin{array}{c}\text { Tourism } \\
\text { Quotient }\end{array}$ \\
\hline \hline Region of Bratislava & 1.579 & 0.331 & 0.057 & 1.969 \\
Záhorie & 0.209 & 0.043 & 0.575 & 0.829 \\
Lower Považie & 0.403 & 0.084 & 0.239 & 0.728 \\
\hline Region of Nitra & 0.447 & 0.093 & -0.135 & 0.406 \\
Upper Nitra & 0.384 & 0.080 & -0.040 & 0.425 \\
\hline Upper Považie & 0.386 & 0.081 & 0.512 & 0.980 \\
Turiec & 0.183 & 0.038 & -0.149 & 0.073 \\
Orava & 0.130 & 0.027 & 0.138 & 0.296 \\
Liptov & 0.249 & 0.052 & 0.225 & 0.528 \\
\hline Horehronie & 0.281 & 0.059 & -0.040 & 0.300 \\
Pohronie & 0.224 & 0.047 & 0.003 & 0.275 \\
Tatras & 0.342 & 0.071 & -0.282 & 0.131 \\
Spiš & 0.265 & 0.055 & -0.494 & -0.173 \\
Šariš & 0.289 & 0.060 & 0.404 & 0.755 \\
\hline \hline
\end{tabular}

The most significant increase in the total number of employees in tourism from all tourist regions was clearly recorded in the region of Bratislava, and (with a significant gap) regions of Upper Považie, Šariš, Lower Považie, Záhorie, Liptov and Upper Nitra. All these regions are those that also achieve above-average LQ values, however only the region of Liptov achieved the level of regional specialization in tourism. Most jobs were created as a result of the region's competitiveness in tourism (regional component) in regions of Upper Považie, Šariš and Záhorie, in all of which the high increase in the number of employees can be clearly explained by the region's competitiveness. On the contrary, in the region of Bratislava, Upper Nitra and the region of Nitra, the regional component is a negative item; employment growth must be clearly attributed mainly to the growth of the national economy. In regions of Lower Považie and Liptov, the high growth of the number of employees in tourism is roughly the same due to the national component and the competitiveness of the region in tourism.

The only region that showed a decrease in the number of employees in tourism in the period under review is region of Spiš, which, however, reaches the level of sectoral specialization in tourism. Its competitiveness in tourism (high negative regional component) plays a negative role here, but the region is included among the regions of $1^{\text {st }}$ category. The regions of Turiec and Horehronie (with a negative regional component), region of Pohronie (in which of the three components monitored, competitiveness contributed the least to growth), and region of Orava (in which the region's competitiveness and national economic growth played roughly the same level) all had low employment growth rates. Of the examined regions, there is also region of Tatras the region of the $1^{\text {st }}$ category and a branch specialization in tourism - in which employment growth in tourism was minimal, even well below average. This was mainly due to region's low competitiveness in tourism, whereas the low (but nevertheless positive) change in employment was mainly due to the national component.

Regarding the importance of the regional component across tourist regions, the highest values are achieved in the regions of Upper Považie, Šariš and Záhorie. These three regions do not achieve the largest positive change in employment in the same period under review, but belong 
to regions with above-average change. The change in employment in tourism in the regions was negatively affected by the regional component in many regions of Slovakia, in particular the region of Spiš, the region of Tatras and the region of Bratislava. For all these regions, the national component was clearly the most important. All three regions belong to the regions of $1^{\text {st }}$ category, and among these, significant competitiveness in tourism is clear only in the region of Upper Považie, and in both Orava and Liptov regions roughly as important as the national component.

\subsection{The most vulnerable regions during crisis}

In connection with the current outages of tourism caused by global measures to stop the COVID19 pandemic in the most important regions, the greatest assumption is that their economy will be most negatively affected and, through them, tourism in Slovakia as a whole. From the research, it is possible to draw attention to the most endangered and most vulnerable tourist regions, especially the region of Liptov, but also Orava, Spiš and Tatras, which reach the level of industry specialization in tourism. Therefore, we are assuming the biggest negative impacts for these four regions, however, at the same time, their concentration on tourism is developing differently. Continuous growth of specialization in tourism is evident in the region of Orava ( $L Q=0.83$ in 2007; $L Q=1.12$ in 2012; $L Q=1.61$ in 2018) with almost $94 \%$ growth compared to 2007 and also in the region of Liptov with $42 \%$ growth ( $L Q=1.52$ in $2007 ; L Q=1.91$ in $2012 ; L Q=2.16$ in 2018). On the contrary, the $L Q$ is constantly decreasing in the region of Tatras $(L Q=2.01$ in 2007; $L Q=$ 1.51 in 2012; $L Q=1.23$ in 2018) by up to $39 \%$ compared to 2007 and in the region of Spiš by $33 \%(L Q=2,25$ in 2007, $L Q=1.86$ in 2012, $L Q=1.51$ in 2018). The decline in specialization in the region of Spiš is the highest one of all tourist regions in Slovakia. In terms of the development of specialization in tourism, particularly, the regions of Liptov and Orava can be considered the riskiest in times of crisis. All four regions belong to the regions with the highest potential for the development of tourism and the growth of tourism expressed by the development of the number of overnight stays in them is above average, with the exception of the region of Spiš. In fact, these regions are traditional ones based mainly on localization assumptions with a less developed economic structure. In terms of tourism in Slovakia (according to the number of nights), the regions of Tatras and Liptov ranked second and third among the regions. On the contrary, in this very respect, regions of Orava and Spiš are on the lower ranks of importance. In all of these regions, about two-thirds of all visitors are predominately domestic ones (Tab. 1) - mostly in the region of Orava.

However, based on the performed shift-share analysis (Tab. 3), none of these regions belongs to the regions with the highest positive change in employment due to the regional competitiveness of tourism. In the regions of Orava and Liptov, the regional component plays the largest role (but only slightly larger than the national component). In the regions of Tatras and Spiš, it has a negative impact (high negative values, mostly in the region of Spiš of all regions of Slovakia), while region Spiš is one of the regions with an overall decrease in employment in tourism between the years 2012-2018 (value of the coefficient of the tourist region - 0.173, see Tab. 3), but also in 2007 and 2018 (value of the coefficient of the tourist region at the level of - 0.185). For the years 2007-2018, only two regions had a negative value of the coefficient of the tourist region, and these are both the two regions of Spiš and Tatras mentioned before, and both these regions are at the same time with a negative value of the regional component. In all four regions, the growth of the national economy is significant.

\subsection{Institutional provision of tourism in the most important regions}

Tab. 4 schematically shows the institutional provision of tourism development in the identified most important regions. It depicts the regions in different colour according to the level of industry concentration of tourism, tourist regions of the $1^{\text {st }}$ category (with international significance) and regions with an above-average number of overnight stays. It is instantly obvious from the chart, that the institutional provision of tourism is very diverse in each region.

The Cluster ORAVA tourism cluster organization has been operating in the region of Orava since 2009. With the establishment of the DMO Cluster Orava (2012), this new organization in tourism completely coincides with the cluster organization, both territorially and as a membership base. 
The cluster organization has almost identical focus as the DMO in this area - which is the creation of a positive image of the region for visitors, investors and citizens of the region, joint marketing of tourism, and joint offer of quality products of tourism. Half of all the 26 members of the membership base are municipalities and the DMO has members located throughout the entire region. In addition to these two organizations in the region, another Cluster Oravaregión organization was founded with a very low number of members based on the Orava Castle sightseeing attraction (the member municipality of Oravský Podzámok, where the castle is located, and is not a member of any of the above organizations).

Basically, everything that was mentioned about Orava also applies in the region of Liptov. Cluster organization Cluster LIPTOV - tourism association has been operating in the region since 2008, but DMO Region Liptov (founded in 2012) has a larger membership base in the region. This was also created by merging the originally established DMOs, namely Jasná and Liptovský Ján Turizmus (= Tourism). The cluster organization, which aims to increase tourism in the region, is a member of the DMO. The intent of the DMO may be formulated differently, but it is essentially a similar focus for both organizations. As with the Orava $\mathrm{DMO}$, about half of the rather smaller DMO membership base (20 members) is also made up of municipalities.

Destination management organizations dominate in the region of the Tatras, and four such organizations have been operating here since the effectiveness of the law, partly intervening in the territory outside the tourist region of the Tatras. There is neither any existing cluster organization here, nor was one created in the past. In this region, however, in the past, in the period of non-systematic development of tourism in the regions and completely absent support for regional development of tourism from public sources, regional association of tourism was endogenously developed in the High Tatras with a membership base of 130 members and it performed the tasks of destination management. As such, the association did not "transform" into a regional organization after the effectiveness of the Tourism Promotion Act, but became a member of the new 6-member Tatra DMO Region Vysoké Tatry, which covers the geographically largest area of the region. The core of this DMO product is the High Tatras themselves. Other DMOs, despite their wider membership base, have a territory in which they operate, "scattered", non-compact, extending to different areas of the region. Within one area of the region, two to three DMOs with different members operate at the same time, and some of these DMOs extend as far as the neighbouring region of Spiš. Their territory is covered by attractions of various kinds.

The situation is similar in the region of Spiš. There are two destination management organizations actively operating here. One of them, Slovenský raj \& Spiš, is built around the centre of Spiš Spišská Nová Ves and relies on the core of the product based on the Slovak Paradise National Park and Spiš cultural and historical monuments, while in order to preserve the integrity of the Slovak Paradise and product continuity, this DMO extends in the west partly into the territory of the neighbouring region of Gemer One of the Tatra DMOs - LTO Tatry - Spiš - Pieniny - also extends into the region of Spiš (especially through its easternmost part, namely the village of Spišské Podhradie, the village below the largest castle in Central Europe - Spiš Castle). There is neither any existing cluster organization in this region, nor was one created in the past.

Upper Považie belongs to the regions of $1^{\text {st }}$ category, but with a localization coefficient below 1.01 (however, the concentration of tourism in this region is continuously increasing). Within the region, some subregions are clearly profiled, which correspond to 4 DMOs located in its territory, namely Kysuce Tourist Board in the northern part of the region based mainly on winter tourism (skiing) and natural aspects of the area, DMO Malá Fatra in the east-northeast based on the town of Žilina and the Malá Fatra Mountains, in the south-southwest DMO Horné Považie Tourist Association connected to the centre of Považská Bystrica and spa tourism, and finally DMO Rajecká dolina in the south-southeast with a specific product within spa tourism and natural aspects related to Rajecká Valley. No cluster organization (in tables abbreviated to $\mathrm{CO}$ ) has emerged in the region. Covering of each individual subregion by DMOs is natural in this phase of the development of destination management in Slovakia. In the past, even before the use of public resources for cooperation efforts in the regions, there was an active LTA Terchová, and therefore, DMO Malá Fatra could base its establishment on LTA Terchová's experience with cooperation. 
Tab. 4 Institutional provision of tourism in the most important regions of Slovakia.

\begin{tabular}{|c|c|c|c|}
\hline Region & DMO & Notes & Cluster Organization \\
\hline Orava & Cluster Orava & $\mathrm{DMO}=\mathrm{CO}$ & $\begin{array}{c}\text { Cluster ORAVA, } \\
\text { Cluster Oravaregión }\end{array}$ \\
\hline Liptov & Region Liptov & $\mathrm{DMO}=\mathrm{CO}$ & Cluster LIPTOV \\
\hline Tatras & $\begin{array}{l}\text { Region Vysoké Tatry, } \\
\text { LTO Tatry - Spiš - Pieniny, } \\
\text { Severný Spiš - Pieniny, } \\
\text { High Tatras - Foothills. }\end{array}$ & $\begin{array}{l}\text { Geographically } \\
\text { integrated areas of } \\
\text { individual DMOs are } \\
\text { not created in the } \\
\text { region. }\end{array}$ & - \\
\hline Spiš & $\begin{array}{c}\text { Slovenský raj \& Spiš, } \\
\text { LTO Tatras - Spiš - Pieniny } \\
\text { extends here }\end{array}$ & & $x$ \\
\hline $\begin{array}{l}\text { Upper } \\
\text { Považie }\end{array}$ & $\begin{array}{l}\text { Horné Považie Tourist } \\
\text { Association, Rajecká dolina, } \\
\text { Kysuce Tourist Board, } \\
\text { Malá Fatra. }\end{array}$ & $\begin{array}{l}\text { Different DMOs } \\
\text { operate in different } \\
\text { natural subregions. }\end{array}$ & $x$ \\
\hline Záhorie & LTO Záhorie & & $\begin{array}{l}\text { Cluster of regional } \\
\text { Development - Western } \\
\text { Slovakia extends here }\end{array}$ \\
\hline $\begin{array}{l}\text { Region of } \\
\text { Bratislava }\end{array}$ & $\begin{array}{l}\text { Bratislava Tourist Board, Senec } \\
\text { Region, The Small Carpathians, } \\
\text { LTO Záhorie extends here }\end{array}$ & $\begin{array}{l}\text { Different DMOs } \\
\text { operate in different } \\
\text { natural subregions. }\end{array}$ & $\begin{array}{l}\text { Cluster of regional } \\
\text { Development - Western } \\
\text { Slovakia extends here }\end{array}$ \\
\hline $\begin{array}{l}\text { Lower } \\
\text { Považie }\end{array}$ & $\begin{array}{l}\text { Trnava Tourism, } \\
\text { Rezort Piešt'any }\end{array}$ & $\begin{array}{l}\text { By targeting different } \\
\text { organizations with a } \\
\text { specific mission. }\end{array}$ & $\begin{array}{c}\text { Cluster of regional } \\
\text { Development - Western } \\
\text { Slovakia, } \\
\text { Cluster Smolenice }\end{array}$ \\
\hline $\begin{array}{l}\text { Upper } \\
\text { Nitra }\end{array}$ & $\begin{array}{c}\text { Region Horná Nitra - Bojnice } \\
\text { (North) }\end{array}$ & $\begin{array}{l}\text { DMO and CO have } \\
\text { different territories } \\
\text { (South and North } \\
\text { division). }\end{array}$ & $\begin{array}{l}\text { Cluster TOPOL'ČANY } \\
\text { (South - territory of one } \\
\text { district) }\end{array}$ \\
\hline Turiec & Turiec & $\begin{array}{c}\text { CO in the north - the } \\
\text { same territory as DMO } \\
\text { Turiec; DMO has a } \\
\text { non-compact territory - } \\
4 \text { territories in different } \\
\text { parts of Turiec. }\end{array}$ & $\begin{array}{l}\text { Cluster TURIEC (only in } \\
\text { the north, a small CO), } \\
\text { Cluster of the Kremnica } \\
\text { Mountains partially } \\
\text { extends to the region }\end{array}$ \\
\hline Pohronie & $\begin{array}{l}\text { Banská Štiavnica Tourism, } \\
\text { REGION GRON, Turiec } \\
\text { extends here, Tour Novohrad } \\
\text { and Podpol'anie, Central } \\
\text { Slovakia Tourist Board }\end{array}$ & $\begin{array}{c}\text { Part of the CO area is } \\
\text { the same as DMO } \\
\text { Turiec. }\end{array}$ & $\begin{array}{c}\text { Cluster of the Kremnica } \\
\text { Mountains (compact area } \\
\text { of CO - Kremnica and its } \\
\text { surroundings) }\end{array}$ \\
\hline Horehronie & $\begin{array}{l}\text { Region Horehronie, } \\
\text { Central Slovakia Tourist Board. }\end{array}$ & $\begin{array}{c}\text { The Region Horehronie } \\
\text { DMO has the same } \\
\text { membership base with } \\
\text { the Cluster } \\
\text { HOREHRONIE; CO is } \\
\text { a member of the DMO. }\end{array}$ & Cluster HOREHRONIE \\
\hline Šariš & $\begin{array}{l}\text { Šariš Region, } \\
\text { "Šariš" - Bardejov. }\end{array}$ & $\begin{array}{l}\text { DMO and CO (different } \\
\text { territories). }\end{array}$ & $\begin{array}{l}\text { Tourism Cluster - Šariš, } \\
\text { Tourism Cluster - } \\
\text { Slanské Mountains also } \\
\text { extends here. }\end{array}$ \\
\hline $\begin{array}{l}\text { Region of } \\
\text { Nitra }\end{array}$ & $\begin{array}{c}\text { Nitra Tourist Board, } \\
\text { REGION GRON, } \\
\text { Regional Tourism Organization } \\
\text { Tekov }\end{array}$ & & 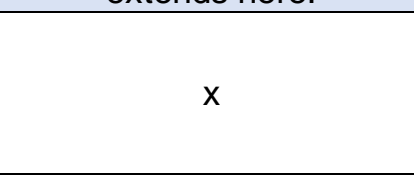 \\
\hline
\end{tabular}

Note:

CO stands for Cluster Organisation.

The tourism regions of the $1^{\text {st }}$ category (with international significance) are marked in dark blue. Dark blue filled-areas are used for regions with LQ above 1.2. Pale blue filled-areas are used for regions with LQ 1.01-1.19. Regions entitled in bold are regions with an above-average number of overnight stays (2018). 
The region of Záhorie is dominated by LTO Záhorie, however, no cluster organization is located on its territory. Some members of this LTO from the northern part of the region are members of the cluster organization Cluster of regional Development - Western Slovakia, which is profiled as interregional with its centre around the city of Trnava and in the Tourism Lower Považie region (operates in 4 tourist regions and falls into two administrative regions). This cluster organization was established as one of the first in Slovakia (2008), and until then efforts to cooperate with regional entities in tourism were not obvious. LTO Záhorie covers basically the entire territory of the region, northern and southern part of Záhorie (with 43 entities in its membership base) and its activities are mainly related to the use of the potential of viticultural tourism and also cultural and cognitive urban tourism. Until the effectiveness of the Tourism Promotion Act, no regional organization or association specifically supporting the development of tourism was active here.

The region of Bratislava is characterized by the operation of three destination management organizations, while Bratislava itself is dominated by the DMO Bratislava Tourist Board with one of the largest member bases in Slovakia (76 members in a single city). Some members of this DMO are members of the already mentioned cluster organization Cluster of regional Development - Western Slovakia. Until the Act came into effect, there was no organization or association specifically supporting the development of tourism in the city. Within the region, two DMOs were profiled outside the city Bratislava. DMO Senec Region operates in the territory of the former tourism administration (state administration, later a self-governing body, currently an L.L.C. and a member entity of this DMO) in the area of Senec Lakes. DMO The Small Carpathians was built on the foundations of historically one of the most active regional tourism associations in Slovakia (even in the period without the support of regional tourism from public sources) of the Malokarpatská vínna cesta (i.e. Wine Route) Association. Nowadays, this DMO covers the southern part of the region of Malé Karpaty, respecting the administrative boundaries of the regions, while the northern part of the region of Malé Karpaty is not covered by the destination management organization. There is no cluster organization of tourism in this area outside Bratislava where the two DMOs operate. Some subjects of the northern part of the region of Bratislava are members of the LTO Záhorie - in this case, more than the administrative borders, the homogeneity of the area in terms of tourism was respected.

The region of Lower Považie region has a strong cluster organization entitled the Cluster of regional Development - Western Slovakia (formerly the Cluster of Tourism - Western Slovakia), which, as mentioned above, has a supra-regional dimension - extending to the region of Bratislava, Záhorie and the region of Danubeland. However, it is located mainly in the region of Lower Považie, while the representation of the membership base is pretty much even in the whole region. Its focus is similar to the focus of DMOs operating in the region - on the principle of partnership, it should activate and support the development of tourism in the region. However, two DMOs are considered strong destinations with a special offer within the region - DMO Trnava Tourism corresponds to a separate destination Trnava itself with its immediate surroundings and DMO Rezort Pieštany corresponds to a spa destination Pieštany. There is another cluster organization operating in the region - Cluster Smolenice, which is a civic association, with its membership base partially overlapping with DMO Trnava Tourism through the common interest, especially around the Smolenice Castle.

The region of Upper Nitra has a cluster organization Cluster TOPOL'ČANY - a tourism association, in the south-western part of the region, which focuses on the effective and systematic functioning of partnerships in the field of tourism, improving and promoting tourism services and products, especially in the district of Topol'čany. In the north of the region, there is DMO Region Horná Nitra - Bojnice, which belongs to organizations with a larger membership base (56 members, of which there are 6 local governments). The cluster organization in the region is neither a member of the $\mathrm{DMO}$, nor the other way around. Both of them have divided the territory, with the DMO focusing mainly on the support of adventure tourism (mining, the Bojnice Castle) and spas. Even before the act came into effect, the Regional Tourism Association of Upper Nitra had been active in the core of the territory of today's DMO. It can be said that today's DMO was built on the basis of endogenous cooperation of the then association.

The region of Turiec has one DMO Turiec, which operates in this region, but extends through region of Kremnicko (Kremnica and its surroundings) mainly through the civic association 
Kremnica Region - a tourist association which also extends into the northern part of the second region Pohronie. In northern part of Turiec, the membership base coincides with the cluster organization Cluster TURIEC - a tourism association, which is also a member of this DMO. Kremnicko has its cluster organization Cluster of the Kremnica Mountains - a tourism association, but with a wider base than the base from this region in DMO Turiec. Thus, there are several functional organizations operating here side by side, whose territories and members partially overlap. For instance, DMO Turiec has the largest membership base and at the same time operates in various areas across the region.

In the region of Pohronie, the already mentioned cluster organization Cluster of the Kremnica Mountains, which partially overlaps with the DMO Turiec, operates in the north of the region. There are four (or, actually, five) DMOs, two of which represent the specific core of the cognitive tourism - historical heritage (mining), Štiavnické Mountains and spa tourism. These are the DMO Banská Štiavnica Tourism (with a large membership base of 70 members) and the DMO REGION GRON. In the east, there is DMO Tour Novohrad and Podpolanie intervene in the region through the membership of several entities (e.g. through the municipality of Detva, with this neighbouring DMO in the region of Poiplie as its core). In the northeast, there is LTO is Central Slovakia Tourist Board (for example, as a member of the town of Zvolen, administratively and properly extending north to the town of Banská Bystrica in terms of proximity to towns and their economic ties, while this neighbouring $\mathrm{DMO}$ in the Horehronie region has its core). In these cases, rather than the administrative borders, or the ones within the designated tourism region, tourism assumptions (especially localization assumptions) and their affiliation to the core product of neighbouring regions were preferred. This is evidenced by the logical affiliation of some entities to DMOs in the neighbouring region.

In the region of Horehronie, the cluster organization Cluster HOREHRONIE - a tourism association territorially covers about half of the DMO Region Horehronie, which was established a year later. It can be stated that the DMO developed from a cluster organization and expanded its membership base to other territories in the central part of Horehronie and partly in the east of the region. Nevertheless, this DMO has only 17 members (of which there are 12 municipalities), while one of the members is the Cluster HOREHRONIE - a tourism association. Within the western part of the region, LTO Central Slovakia operates located in the natural administrative centre of Horehronie, in Banská Bystrica and its surroundings, while its membership base is much larger than the previous $\mathrm{DMO}$, which provides a larger area of the region. In essence, the territory was divided by these organizations - the centre and east of the region falls within the scope of DMO Region Horehronie (or its cluster organization), west part of the DMO falls under Central Slovakia.

The region of Šariš has two DMOs - the DMO Šariš Region (operating mainly in the south, as region with its centre in Prešov and some other territories to the west) and the DMO "Šariš" Bardejov (operating in the north), which operates rather locally in town of Bardejov and the more distant town of Svidník in the northeast. Both DMOs have a relatively low number of members (12 and 5). There is also a cluster organization Tourism Cluster - Sariš located in the region, located mainly in the southwest, its territory differs from the territory of both DMOs. The region is also covered by the supraregional cluster organization Tourism Cluster - Slanské Mountains, which corresponds to the territory of Prešov and the south-east of the region of Šariš, as the territory of the cluster maps the Slanské Mountains and thus extends to other regions as well. All DMOs as well as cluster organizations have geographically divided territories in which they operate, so the entire territory of the region is pretty much covered by various organizations.

There are three destination management organizations operating in the Region of Nitra the regional city of Nitra (which is the centre of the Nitra Tourist Board), DMO REGION GRON (located in the north-east with the largest membership base of these three organizations), and the new Regional Tourism Organization Tekov (located in the east). Until the act came into effect, no regional tourism support organization or association was active in the territory. Currently, operating DMOs build on the specifics of the region based on cultural conditions (the city of Nitra), natural conditions (the river Hron) and the historic region of Tekov. By using two different criteria in the formation of the institutional provision of the Hron and Tekov subregions, some municipalities of the historical region of Tekov are included in the DMO REGION GRON. 


\section{Conclusion and discussion}

Institutional security in the Slovak regions, despite the uniform system set out in the Tourism Promotion Act, has different variants for all regions. We have identified 5 basic variants:

- one DMO operating a) across the whole region, b) only in some subregion, or some subregions of the region;

- $\quad$ two or more DMOs "divided" the territory of the region, they are profiled in different natural (logical) subregions of the region, or in subregions corresponding to specific tourism products, or are profiled on the basis of other criteria, such as political ones, previous ties, ties to stronger stakeholders, etc. Such DMOs are considered comparably strong, or one of them is more dominant than the other ones. They operate in the territory of one region or, for the same reasons as mentioned above, intervene in neighbouring regions of tourism;

- $\quad$ two or more DMOs operating in the same tourism product core (in the same subregion) but with different membership base from the same subregion (reasons are political ones or other contradictions or even disagreement on the choice of product core criterion / substance) - one organization focused on a natural attraction, the other on the cultural specificity of the subregion;

- $\quad \mathrm{DMO}$ and cluster organization in the region (i.e., similar situation as in the previous point) but not always in different territories; organizations also operate in partially overlapping territories, with partially overlapping membership base (but at the same time each of them gained other regional stakeholders for cooperation);

- $\quad$ DMO and cluster organization - two identical (or almost identical) organizations - either territorially (geographically), or through a member organization (i.e., they build on the same basis, or rely on the same core of the product of tourism).

Despite the existence of different DMOs with different (or even overlapping) territories, large parts of the regions remain uncovered. In several regions, destination management organizations are in competition with each other, elsewhere they profile themselves in their subregions and have the potential to become mutual business partners. The setting of rules for the establishment and financing of DMOs in Slovakia so far allows the existence of several DMOs in the same region or subregion. The reasons for the co-existence of DMOs and cluster organizations are mentioned in the introduction - cluster organizations operate in various forms in most of the examined regions, regardless of the level of concentration of tourism in the territory or a specific cluster policy in tourism. The most vulnerable regions of Orava, Liptov, Tatras and Spiš have a well-established destination management on the institutional level, and also active DMOs, which have emerged from cluster tourism organizations or former regional tourism associations, and which build on the previous institutionalized regional cooperation in tourism. There are four DMOs operating in the Tatras and, sooner or later, the re-organization of destination management will be necessary, since Orava and Liptov are building one DMO each, and in fact the region of Spis is mainly represented by one DMO. With the gradual expansion of the membership base and the development of their activities, these DMOs could be profiled as organizations ensuring the development of tourism, responsible for the entire tourism region and representing the interests of regional entities at the regional level in the regional tourism organization. The effectiveness of duplication of several identical or similar institutions in one region under different "headings" is questionable.

Our research showed that the regions of Tatras and Liptov are those that are above average in all three basic criteria examined - namely in the potential for tourism development, in the number of overnight stays ( $2^{\text {nd }}$ and $3^{\text {rd }}$ most important region), in the level of industry concentration of tourism (with region of Liptov on the $1^{\text {st }}$ place). Both of these regions also achieve an aboveaverage increase in the number of overnight stays, however, their difference in the development of the concentration of tourism and in the factor of its change is quite markable. While the region of Liptov is developing towards an increasing concentration of tourism with a growing number of employees in tourism due to its regional competitiveness and overall growth of the national economy, the region of Tatras is a gradual decline in the concentration of this sector and 
a decrease in total employment in tourism caused by factors based on shift-share analysis especially the low competitiveness of the region in tourism. The difference in the development of the concentration of tourism is also in the regions that do not reach the above-average number of overnight stays, but belong to the regions with high potential of tourism - regions of Orava and Spiš. While in Orava, the importance of tourism in this region is constantly growing and the positive changes in employment in tourism were mostly due to the competitiveness of tourism in the region quite the same as the national component, region of Spiš marks the very opposite development. However, despite the established destination management in these regions, the competitiveness of tourism in these four regions does not have a clear positive position.

Especially for those regions that we have identified as the most vulnerable ones, in the current situation of the crisis and the collapse of tourism, it is essential to maintain their socio-economic level to restore jobs as soon as possible, or to prevent any further decline (a decrease between the $1^{\text {st }}$ and $2^{\text {nd }}$ quarters in 2020 in the conditions of Slovakia in employment in tourism is $12.49 \%$, in number of visitors is $78.80 \%$ and in number of overnight stays is $75.38 \%$ ). In the context of destination management, it is a matter of maintaining support for tourism through public resources in connection with the Tourism Promotion Act and the promotion of destination management organizations as beneficiaries of European Structural and Investment Funds in the new budget period. However, this support is fragmented among several organizations, and nowadays, it is even more important than ever that their competitive battle, or operating with fewer resources from several organizations was not counterproductive. It is possible that the current crisis period will help to find endogenous solutions to fragmented destination management in the most important and also the most vulnerable regions of tourism, or legislative solutions related to the amendment of the Tourism Promotion Act and the innovation of the model of the functioning of destination management in our country will also be sought. The structure of visitors in all researched important regions of Slovakia (outside the region of Bratislava) is composed mainly of domestic tourists, support for domestic tourism and through the support of DMO activities (but also other tools) can be one of the key ones for tourism in Slovakia and the most important regions of Slovakia.

The study has its limitations. First, in identifying the most important regions of tourism, we operate with indicators that have a limited informative value. The indicator of the number of overnight stays does not comprehensively tell us about the performance of tourism, it does not capture excursion-type of tourism, which is essential for many regions. Employment in tourism (used in both LQ and in shift-share analysis) is an indicator capturing jobs in section NACE I 55 and 56.

In the future, it will be necessary to monitor the development of institutional provision of tourism in the regions, the emergence of new organizations, merging existing organizations into stronger organizations, the demise of some organizations in order to build strong, meaningful and effective destination management capable of supporting tourism competitiveness in the region and provide jobs to exploit the region's tourism potential.

\section{Acknowledgement}

This contribution is the part of the project KEGA no. 034EU-4/2020 entitled "Content and technical innovation approaches to teaching regional tourism".

Academic references

[1] Aiginger, K. \& Davies, S. W. (2004). Industrial specialisation and geographic concentration: Two sides of the same coin? Not for the European Union. Journal of Applied Economics 7(2), 231-248. DOI: 10.1080/15140326.2004.12040610.

[2] Benešová, D., Kubičková, V. \& Krošláková, M. (2013). Služby v poznatkovej ekonomike prípadové štúdie. Bratislava: Vydavatel'stvo EKONÓM.

[3] Bieger, T. \& Beritelli, P. (2012). Management von Destinationen. München: Oldenbourg Verlag. 
[4] Bielik, P. \& Rajčániová, M. (2008). Shift-share analysis of employment growth - The case of the V4 countries. Agricultural Economics - Czech, 54(8), 347-351.

[5] Brakman, S., Garretsen, H. \& van Marrewijk, C. (2001). An Introduction to Geographical Economics. Cambridge: Cambridge University Press.

[6] Bratl, H. \& Schmidt, F. (1998). Destination Management. Wien: ÖAR-Regionalberatung.

[7] Dupeyras, A. \& MacCallum, N. (2013). Indicators for Measuring Competitiveness in Tourism: A Guidance Document. Paris: OECD Publishing. DOI: 10.1787/5k47t9q2t923-en.

[8] Dwyer, L, \& Kim, C. (2003). Destination competitiveness: A Model and Determinants. Current Issues in Tourism 6(5), 369-414. DOI: 10.1080/13683500308667962.

[9] Estêvão, C. M. \& Ferreira, J. J. (2015). A Competitividade no Setor do Turismo Contributos, desafios e implicações. Porto: Idioteque.

[10] Fesenmaier, D. R. \& Xiang, Z. (2017). Design Science in Tourism: Foundations of Destination Management. Cham: Springer International Publishing.

[11] Fuchs, M., Rijken, L., Peters, M. \& Weiermair, K. (2000). Modelling Asian incoming tourism: A shift-share approach. Asia Pacific Journal of Tourism Research, 5(2), 1-10. DOI: 10.1080/1094166008722067.

[12] Gajdošík, T. (2019). Manažérske organizácie v cieĐových miestach cestovného ruchu. Banská Bystrica: Belianum.

[13] Gáll, J. \& Strežo, M. (2019). Quantitative Analysis of Environment Potential for Cluster Development in Tourist Regions of Slovak Republic. Geographica Pannonica, 23(3), 195203. DOI: $10.5937 / g p 23-21375$.

[14] Haggett, P. (1965). Locational Analysis in Human Geography. London: Edward Arnold.

[15] Herath, J., Gebremedhin, T. G. \& Maumbe, B. M. (2011). A Dynamic Shift Share Analysis of EconomicGrowth in West Virginia. Journal of Rural and Community Development, 6(2), 155169.

[16] Holešinská, A. (2012). Destinační management jako nástroj regionální politiky cestovního ruchu. Brno: Masarykova univerzita.

[17] Hoover, E. M. (1936). The Measurement of Industrial Localization. The Review of Economics and Statistics, 18(4), 162-171. DOI: 10.2307/1927875.

[18] Indrová, J., Jarolímková, L., Királ'ová, A., Mlejnková, L., Petrů, Z. \& Štěpanovská, R. (2008). Cestovní ruch pro všechny. Praha: Ministerstvo pro místní rozvoj ČR.

[19] Kaspar, C. (1995). Management im Tourismus. Eine Grundlage für die Führung von Tourismusunternehmungen und -organisationen. Bern: Paul Haupt.

[20] Kim, S. (1995). Expansion of Markets and the Geographic Distribution of Economic Activities: The Trends in U. S. Regional Manufacturing Structure, 1860-1987. The Quarterly Journal of Economics, 110(4), 881-908. DOI: 10.2307/2946643.

[21] Királ'ová, A. (2003). Marketing destinace cestovního ruchu. Praha: Ekopress, s.r.o.

[22] Kiser, D. (1992). A Location Quotient and Shift Share Analysis of Regional Economies in Texas. [Master thesis]. San Marcos: Texas State University.

[23] Klein, D., Kies, U. \& Schulte, A. (2012). Regional employment trends of wood-based industries in Germany's forest cluster: A comparative shift-share analysis of postreunification development. European Journal of Forest Research, 128(3), 205-219. DOI: 10.1007/s10342-009-0258-6.

[24] Knudsen, D. C. (2000). Shift-share analysis: further examination of models for the description of economic change. Socio-Economic Planning Sciences, 34(3), 177-198. DOI: 10.1016/S0038-0121(99)00016-6. 
[25] Kowalewski, J. (2011). Specialization and employment development in Germany: An analysis atthe regional level. Papers in Regional Science, 90(4), 789-812. DOI: 10.1111/j.1435-5957.2011.00355.x.

[26] Laesser, C. \& Beritelli, P. (2013). St. Gallen Consensus on Destination Management. Journal of Destination Marketing \& Management, 2(1), 46-49. DOI: 10.1016/j.jdmm.2012.11.003.

[27] Luft, H. (2001). Organisation und Vermarktung von Tourismusorten und Tourismusregionen: Destination Management. Meßkirch: Gmeiner.

[28] Meriläinen, K. \& Lemmetyinen, A. (2011). Destination network management: A conceptual analysis. Tourism Review, 66(3), 25-31. DOI: 10.1108/16605371111175302.

[29] Michálková, A. (2010a). Faktory úspešnosti regionálnych sietí v cestovnom ruchu. Praha: Oeconomica.

[30] Michálková, A. (2010b). Regionálne siete v cestovnom ruchu. Bratislava: EKONÓM.

[31] Michálková, A. (2013). Koordinovanie rozvoja cestovného ruchu v regióne. Banská Bystrica: DALI-BB.

[32] Michálková, A. \& Fúrova, T. (2017). Current Problems in Destination Management Organizations: The Case of Slovakia. Humanities and Social Sciences: Latvia, 25(2), 72-86.

[33] Michálková, A. \& Gajdoš, T. (2015). Klastrovanie v cestovnom ruchu na Slovensku a jeho potenciál v podpore inovácií a podnikania. Ekonomika a spoločnost: vedecký časopis Ekonomickej fakulty Univerzity Mateja Bela v Banskej Bystrici, 16(1), 58-69.

[34] Michálková, A., Némethová, I. \& Kojdová, H. (2012). Studia commercialia Bratislavensia: scientific journal of Faculty of Commerce, University of Economics in Bratislava, 5(20), 627639. DOI: 10.2478/v10151-012-0014-7.

[35] Mira, M., Moura, A. \& Breda, Z. (2016). Destination competitiveness and competitiveness indicators: Illustration of the Portuguese reality. Tékhne - Review of Applied Management Studies, 14(2), 90-103. DOI: 10.1016/j.tekhne.2016.06.002.

[36] Mori, T., Nishikimi, K. \& Smith, T. E. (2005). A Divergent Statistic for Industrial Localization. Review of Economics and Statistics, 87(4), 635-651.

[37] Novacká, L'., Michálková, A., Volek, M., Drábik, P. \& Litomerický, J. (2013). Destinatour 2013: destinačný manažment cestovného ruchu: metodická príručka destinačného manažmentu pre potreby Bratislavského kraja. Bratislava: Vydavatel'stvo EKONÓM.

[38] Özoğlu, M., \& Gáll, J. (2020). Porovnanie vývoja v cestovnom ruchu abstrahujúc od externých vplyvov so súčasnou situáciou. MERKÚR 2020: Proceedings of the International Scientific Conference for PhD. Students and Young Scientists (pp. 178-189). Bratislava: Vydavatel'stvo EKONÓM.

[39] Pearce, D. G. (2015). Destination management in New Zealand: Structures and functions. Journal of Destination Marketing \& Management, 4(1), 1-12. DOI: $10.1016 / j . j d m m .2014 .12 .001$.

[40] Pechlaner, H., Beritelli, P., Pichler, S., Peters, M. \& Scott, N. (2015). Contemporary Destination Governance: A Case Study Approach (Bridging Tourism Theory and Practice). Melbourne: Emerald Publishing Limited.

[41] Porter, M. E. (1998). Clusters and the new economics of competition. Harvard Business Review, 76(6), 77-90.

[42] Primont, D. F. \& Domazlicky, B. (2008). Industry Cluster Analysis for the Southeast Missouri Region. Cape Girardeau: South-East Missouri State University.

[43] Ray, M. A. \& Harvey, J. T. (1995). Employment Changes in the European Economic Community: A Shift-share Analysis. The Review of Regional Studies, 25(1), 97-110. 
[44] Ritchie, B. J. \& Crouch, G. I. (2010). A model of destination competitiveness/ sustainability: Brazilian perspectives. Revista de Administração Pública, 44(5), 1049-1066. DOI: 10.1590/S0034-76122010000500003.

[45] Sambidi, P. R. (2019). Regional Industry Cluster Analysis for the Gulf Coast Economic Development District. Texas: Gulf Coast Economic Development District and the Houston Galveston Area Council (H-GAC).

[46] Sirakaya-Turk, E., Choi, H.-S. \& Var, T. (2002). Shift-share analysis in tourism: Examination of tourism employment change in a region. Tourism Economics, 8(13), 303-324. DOI: $10.5367 / 000000002101298142$.

[47] Sirakaya-Turk, E., Uysal, M. \& Toepper, L. (1995). Measuring Tourism Performance Using a Shift-Share Analysis: The Case of South Carolina. Journal of Travel Research, 34(2), 5562. DOI: $10.1177 / 004728759503400211$.

[48] Toh, R. S., Khan, H. \& Koh, A.-J. (2001). A Travel Balance Approach for Examining Tourism Area Life Cycles: The Case of Singapore. Journal of Travel Research, 39(4), 426-432. DOI: $10.1177 / 004728750103900409$.

[49] Toh, R. S., Khan, H. \& Lim, L.-L. (2004). Two-Stage Shift-Share Analyses of Tourism Arrivals and Arrivals by Purpose of Visit: The Singapore Experience. Journal of Travel Research, 43(1), 57-66. DOI: 10.1177/0047287504265513.

[50] Xu, N., Cheng, Y. \& Xu, X. (2018). Using Location Quotients to Determine Public-Natural Space Spatial Patterns: A Zurich Model. Sustainability, 10(10), Art. 3462. DOI: $10.3390 /$ su10103462.

\section{Other sources}

[51] Act No. 91/2010 Coll. on Support of Tourism.

[52] A Practical Guide to Tourism Destination Management (2007). Madrid: UNWTO.

[53] Ministry of Transport and Construction of the Slovak Republic. (2020). Register of Destination Management Organization. Retrieved May 21, 2020, from https://www.mindop. sk/ministerstvo-1/cestovny-ruch-7/register-organizacii-cestovneho-ruchu/registeroblastnych-organizacii-cestovneho-ruchu.

[54] Ministry of Transport and Construction of the Slovak Republic. (2020). A Strategy for Tourism Development to year 2020. Retrieved May 17, 2020, from https://www.mindop.sk/ ministerstvo-1/cestovny-ruch-7/legislativa-a-koncepcne-dokumenty/koncepcnedokumenty/strategia-rozvoja-cestovneho-ruchu-do-roku-2020.

[55] OECD (2020). Rebuilding tourism for the future: COVID-19 policy responses and recovery. Retrieved January 27, 2021, from http://www.oecd.org/coronavirus/policyresponses/rebuilding-tourism-for-the-future-covid-19-policy-responses-and-recoverybced9859/.

[56] R Core Team (2020). A language and enviroment for statistical computing. Retrieved June 30, 2020, from R Foundation for Statistical Computing: http://www.R-project.org/.

[57] Statistical Office of the Slovak Republic (2020). Employees by economic activity collected through workplace. Retrieved June 15, 2020, from http://datacube.statistics.sk/\#!/view/sk/VBD_SK_WIN/pr3113rr/v_pr3113rr_00_00_00_sk.

[58] Statistical Office of the Slovak Republic (2020). Employees by economic activity collected through workplace (2001-2008). Retrieved June 15, 2020, from http://datacube.statistics.sk/\#!/view/sk/VBD_SK_WIN/pr3119rr/v_pr3119rr_00_00_00_sk.

[59] Statistical Office of the Slovak Republic (2020a). Capacity and performances of accommodation facilities by districts - yearly data. Retrieved June 20, 2020, from http://datacube.statistics.sk/\#!/view/ sk/VBD_SK_WIN/cr3002rr/v_cr3002rr_00_00_00_sk. 
[60] Statistical Office of the Slovak Republic (2020b). Development of tourism in accommodation facilities in the Slovak Republic in October 2020. Accessed January 27, 2021. Retrieved from https://slovak.statistics.sk/wps/portal/ext/products/informationmessages/inf_sprava_detail/! ut/p/z1/tVJNc5swEP0tOXAUWhAg0Zvs1tiJxx3C4ARdOgILm9olAipO_n3ITi7Nh2d6q uvvd2scCPWGg5NXtpmk7Lk40LEf1 I6YrNZh4HmK0JrG7vss1yvvCTPMQPbwDZfQA8uctp Pk_h-zeChf3maZpm6-

oWkq2_gBXxEtjkOcCCvuZfAYjr_bdYYFFp05sDLrpylAekNGp0jeTROGAf3dBaNZNWaOw HOb04MI3KHO0tA6aYikPEfE-

iolYAsTKq0c5nMIZMhl4ZX8r3VbPDBVQe29UIIBVRi478GJWylCis4tCvAsZqpd7Z8Y7vRQ5 8cjjYfPEHMk_4MqBrALZOQljxZX4fp4QAJ6-

AKzUypXFhedBPeXjW96IRZ5zrizsnnP2jzCXgWyyasnXPVeuCSxkFQikL_CCOQklue9P8f HoS3A6n00Y9G_z4P6Zj-

3BdErbHYIC1GtTg_hrs2h6M6ccvDjhwPp_dfdftT8odjw58IHHoRkvvLyDu2zxvGXIBx_rrblOS B2bCgt_c_AZs44AM/dz/d5/L2dBISEvZ0FBIS9nQSEh/ UNWTO (2020). Impact assessment of the COVID-19 outbreak on international tourism. Retrieved January 27, 2021, from https://www.unwto.org/impact-assessment-of-the-covid-19-outbreak-on-internationaltourism. 